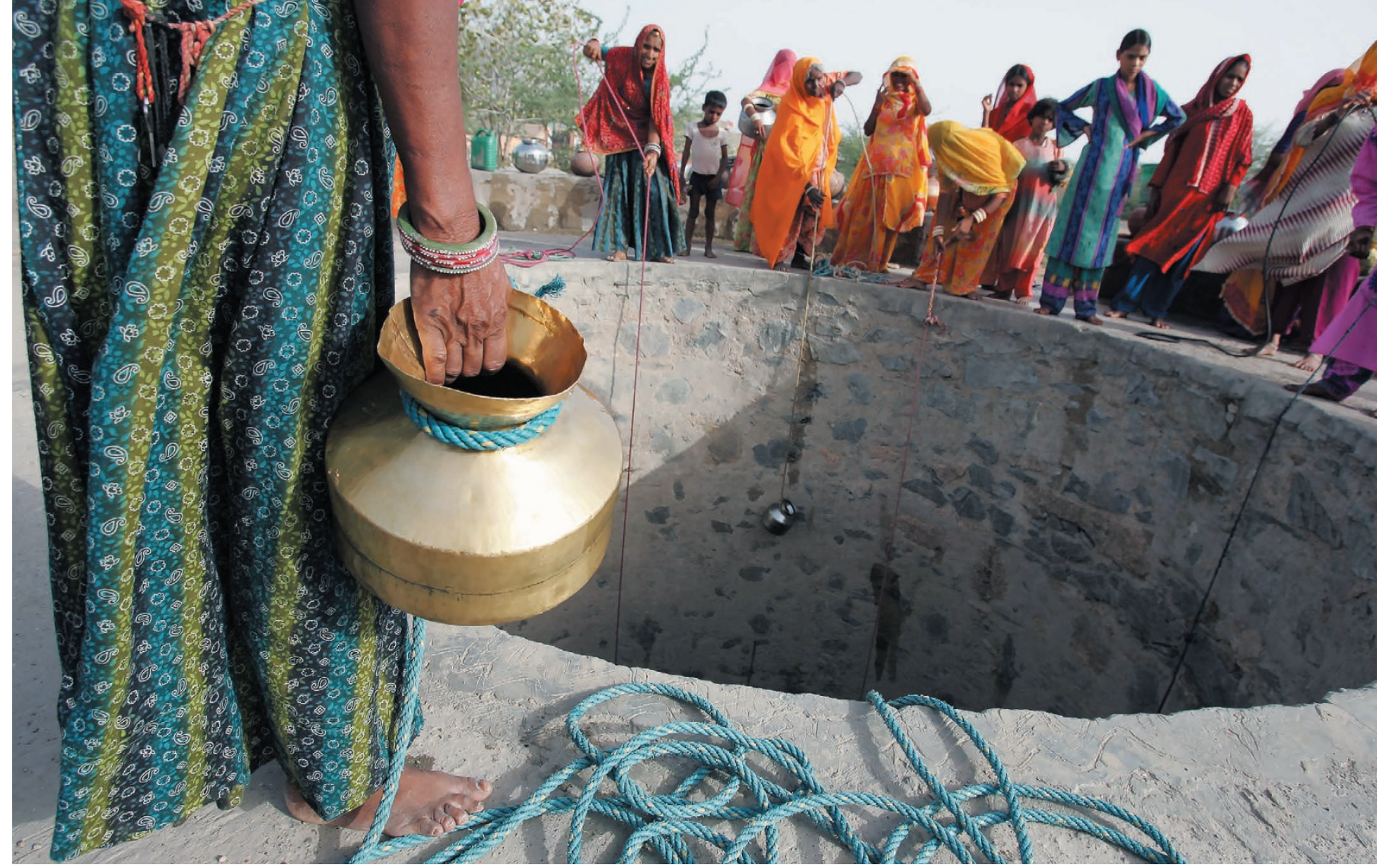

Wells have been a huge boon to living conditions and agriculture in India, but they are fast depleting the country's groundwater.

\title{
The emptying well
}

\section{Margaret Catley-Carlson plunges into a study of a dwindling resource - groundwater.}

$\mathrm{I}$ $t$ is astonishing to many that lakes and rivers account for less than one-third of $1 \%$ of global fresh water. Some $95 \%$ of unfrozen fresh water resides unsung and underground, dimly visible at the bottom of a well or gushing from a pump. Big cities such as Buenos Aires and entire countries, including Germany, depend hugely on groundwater. About 70\% of it goes into irrigation, accounting for more than half of irrigated agriculture - which in turn provides nearly half of the global food basket. In large parts of India, groundwater is egregiously overdrawn. And everywhere, aquifers are poorly measured and managed. As a result, no scientific consensus exists on the details of this vast and vital source of fresh water - although there is consensus on the fact that we face a worldwide problem.

In High and Dry, hydrologist William Alley and science writer Rosemary Alley encapsulate the crisis in a description of the US High Plains Aquifer, which spans eight states from South Dakota to Texas. "This virtual ocean of groundwater, which accumulated over thousands of years, is being used up in decades," they write. In three ways, the book provides a deep and broad understanding of groundwater use and abuse, mostly in the United States but with some international scope.
First, it abounds in case studies, many centring on grand, polarizing projects. In the early twentieth century, engineer William Mulholland fomented water wars in California by diverting the Owens River to Los Angeles; that process has ultimately led to groundwater pumping in the Owens Valley. Today, Texas tycoon T. Boone Pickens has tried to sell water from the Ogallala Aquifer to

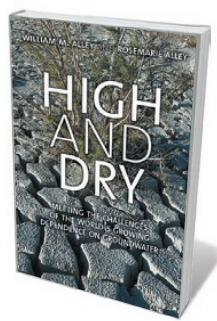

High and Dry: Meeting the Challenges of the World's Growing Dependence on Groundwater WILLIAM M. ALLEY \& ROSEMARIE ALLEY Yale University Press: 2017. municipalities. In the mid-1980s, Libyan leader Mu'ammer Gaddafi masterminded the Great Man-Made River, a piping system fed by the Nubian Sandstone Aquifer, to service the country's dry reaches. India, the Alleys show, swiftly progressed from famine to food exporting beginning in the 1960s. That astonishing development was driven mostly by private pumps ( 16 million of them as of 2010) using free electricity to pull water from an ever-lower water table.
The authors also delve into Australia's Murray-Darling basin, which has been overpumped and overused, largely because of allocations based on volumes in high-water years. And they explore how water politics in apartheid-era South Africa denied nonwhites adequate water rights for rural development. These stories are crucial to global understanding of current imbroglios, and they are told with verve.

The second achievement of High and Dry is its excellent distillation of aquifer science. There are clear descriptions of how geology and geography affect the depth or movement of water, the relation of aquifers to stream flow and how these stores recharge. Pollution of aquifers by pesticides, fertilizers, pharmaceuticals and arsenic is thoroughly laid out, as is arsenic poisoning, which remains slow and expensive to treat. The Alleys show how artesian wells can push pressurized water into the atmosphere and aquifer depletion can cause subsidence of metres per decade, which plays havoc with railways and sewers.

Finally, the book unpicks the tangles that impede groundwater governance. In the United States, the "secret, occult and concealed" nature of the resource, as an 1861 court ruling had it, rendered regulation 
impossible. US history accordingly reveals a rich tapestry of legal suits, counter suits, interstate conflicts, water theft, treaties, compacts, agreements, accords, lobbying, bullying and temporizing. Yet national water governance is slowly finding ways to measure and manage water use as technology and awareness grow. In the American West there are several, sometimes competing, fundamental water laws. "First in time, first in right" means that, during shortages, the earliest registered licence holders get all of the water specified in their licence. The "law of the biggest pump" means that those who can pump it, own it. Water and water rights can be bought and sold: large Californian cities buy huge water allocations from farmers.

Quebec in Canada, where the legal system enshrines the public good over individual rights, has moved more easily towards management. But the Alleys find few unalloyed successes. Under Governor Jerry Brown, California has used the severe droughts of the past decade to create a credible, and broadly supported, groundwater-management agenda. The Murray-Darling region, however, has gone one step forward, one back. In the 2000s, it moved towards a federally managed system based mostly on the public good, but backed off as the rains returned.

The Alleys do examine aquifer replenishment. They cover wastewater recycling through tried and true reverse osmosis, and the increasing use of microorganisms and innovative technologies. They look at rainwater collection in ponds, and well replenishment. But there is little detail, particularly on the actual capacity for meeting challenges. More problematic is the book's US-centrism: Arizona occupies 23 pages, India just 11. Measurements are not primarily metric, which demands translation. And the sub-Saharan sections, concentrating on the work of non-governmental organizations (NGOs), are thin - although they do at least pick up on a fundamental problem. NGOs, engineers and aid programmes come, drill a well and leave. Eventually, the well empties.

The well could empty for millions more. The United Nations Development Programme notes that, in 2011, more than 40 countries experienced water stress; of those, 10 have nearly depleted their renewable freshwater supply. By 2050, one in four people globally may be hit by periodic shortages. The near future could see refugee numbers swell, to include more people without water. Yet High and Dry, like so many books on the environment, is stronger on issues than fixes. More mapping, more statistical detail and a tougher editor might have helped to contextualize and clarify the riches of this book.

Margaret Catley-Carlson is vice-chair of the Canadian Water Network. e-mail:m.catley-carlson@cgiar.org

\section{Books in brief}

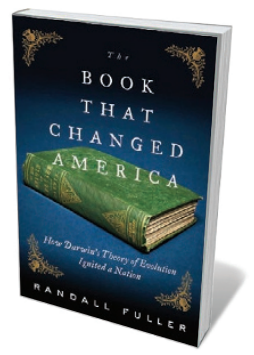

The Book That Changed America: How Darwin's Theory of Evolution Ignited a Nation

Randall Fuller VIKING (2017)

In 1860, when the American Civil War was about to rip the union apart, a bomb of a different kind hit the country. Charles Darwin's On the Origin of Species shattered the world views of several prominent intellectuals, as Randall Fuller's vivid history shows. Botanist Asa Gray became a prominent Darwinian. Abolitionist Franklin Sanborn saw echoes of Darwin's theory in US sociopolitical divisions. And naturalist Henry David Thoreau's observations of forest succession, species and weather became deeply interfused with Darwinian science.

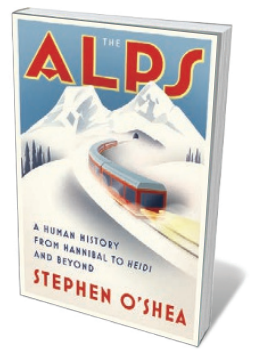

The Alps: A Human History from Hannibal to Heidi and Beyond Stephen O'Shea W. W. NORTON (2017)

Other mountain systems may be as biodiverse and beautiful as the Alps, but few are culturally richer. Over their 800-kilometre arc across 7 European countries, these 1,599 peaks have both divided and nurtured human geographies, creating endlessly fascinating distinctions. Stephen O'Shea's sardonic, science-rich travelogue zips from Johann Wolfgang von Goethe's dislike of the region ("irritating silhouettes and shapeless piles of granite") to the culinary horrors of rösti and geologist Richard Fortey's thoughts on the Insubric Line, where the Adriatic tectonic plate meets Europe's.

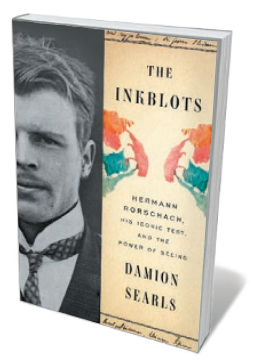

\section{The Inkblots}

Damion Searls CROWN (2017)

Swiss psychiatrist Hermann Rorschach (1884-1922) countered Sigmund Freud in arguing that seeing, not saying, was key to the unconscious - and crafted the ink-blot test to gauge mental health. In this biography, Damion Searls traces myriad influences on Rorschach, from Carl Jung on psychology in its cultural context to philosopher Robert Vischer's work on empathy. An intuitive humanist and empiricist, Rorschach analysed results with sensitivity, and never in isolation. The test's use by others, from its apex in the postwar United States to today, is often less nuanced (see Nature http://doi.org/bzrx; 2017).

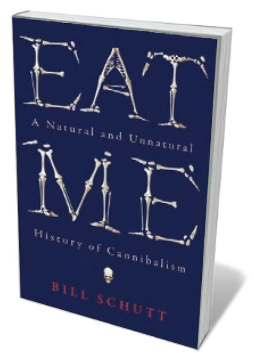

Eat Me: A Natural and Unnatural History of Cannibalism Bill Schutt PROFILE/WeLLCOME COLLECTION (2017)

The case of murderer and putative cannibal Ed Gein (who inspired Alfred Hitchcock's 1960 film Psycho) opens zoologist Bill Schutt's treatise on 'eating one's own'. This is, however, a serious scientific overview of the phenomenon in fauna such as the legless, amphibious caecilians, as well as in us. In laying out the human story, Schutt inevitably dwells on details many will find grisly, from cannibalism in the pre-Neanderthal Homo antecessor to savage cases during the Second World War siege of Leningrad, the consumption of human placentas and the use of human body parts in medicine.

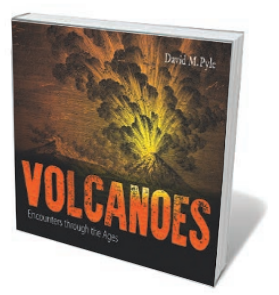

Volcanoes: Encounters through the Ages

David M. Pyle BODLEIAN LIBRARY (2017)

This volume by volcanologist David Pyle almost explodes on the eye, so dramatic are the images and archival illustrations of eruptions and lava flows reproduced in it. Pyle - who curated the linked exhibition at the Bodleian Library of the University of Oxford, UK — is an eloquent guide to the geology and history. But the visuals are the main event, from the lurid painting An Eruption of Vesuvius (1774) by Joseph Wright of Derby to photographs of ash clouds in Iceland and Martinique. A journey into the volcanic sublime. Barbara Kiser 